\title{
The Effects of Workplace Belongingness on Exploratory Innovation: The Mediating Role of Exploitative Innovation
}

\section{Fahri ÖZSUNGUR iD a}

a Adana Alparslan Türkeş Science and Technology University International Trade and Finance, Adana, Turkey. fahri.ozsungur@hacettepe.edu.tr

\begin{tabular}{|c|c|}
\hline ARTICLE INFO & ABSTRACT \\
\hline $\begin{array}{l}\text { Keywords: } \\
\text { Workplace belongingness } \\
\text { Exploratory innovation } \\
\text { Exploitative innovation } \\
\text { IT industry } \\
\text { Received } 21 \text { April } 202 \\
\text { Revised } 7 \text { June } 2020 \\
\text { Accepted } 15 \text { June } 2020 \\
\text { Article Classification: } \\
\text { Research Article }\end{array}$ & $\begin{array}{l}\text { Purpose - The study aims to explore the mediating role of exploitative innovation by revealing } \\
\text { the effects of workplace belongingness and their effects on exploratory innovation in the IT } \\
\text { industry. } \\
\text { Design/methodology/approach - This research was conducted with } 91 \text { executives recruited from } \\
\text { IT businesses registered to Adana Chamber of Commerce in Adana Turkey in December 2019. The } \\
\text { research was analyzed by the structural equation modeling method based on social exchange and } \\
\text { organizational change management theories. } \\
\text { Findings - The results of the study show the positive and significant effects of workplace } \\
\text { belongingness on exploitative and exploratory innovations in the IT industry. To reveal } \\
\text { innovations beyond the existing innovations, the employees' sense of belonging to the workplace } \\
\text { and the existing innovations should be improved. } \\
\text { Discussion - This study is the first to clarify the association between workplace belongingness } \\
\text { and innovation types. There are limitations to the study in the context of sample size and } \\
\text { generalizability. }\end{array}$ \\
\hline
\end{tabular}

\section{Introduction}

Businesses need innovation for sustainable competitive advantage, entering new markets, profitability, and performance (Davey \& Sanders, 2012). Changing consumer needs, future customer concerns ensure the development of existing products and services (Jeffres \& Atkin, 1996). The changes introduced by the technology and the digital world accelerated this development. With the increase in competition, the level of satisfaction of consumers has increased and the existing products and services have become insufficient. The high level of satisfaction has accelerated the innovative actions of businesses (Disney, 1999).

Innovation has an important place in today's business strategies. Businesses need new products and services, processes and supply networks for sustainability and competitive advantage (Saebi \& Foss, 2015). These needs require the creation and improvement of existing products, services, suppliers and processes. This requirement shows that the improvement of existing innovations is not sufficient in the context of changing social structures, technology, and cultural influence. Future customers, new markets, new businesses, new suppliers, new processes, new strategies are essential for today's learning organizations.

Revealing the innovations in businesses depend on the behavior of employees (Bysted, 2013). Employees transform their experience and knowledge gained at workplaces into innovation, thus increasing the performance of the business and intra-organizational coordination. Coordination takes place with individual acceptance and adoption behavior (Frambach \& Schillewaert, 2002). Therefore, improving existing innovations and creating future innovations may depend on individual adoption and belonging behavior (Talukder \& Quazi, 2011). This problem raises the issue of the relationship between belonging and innovation in today's businesses. The practical benefit of investigating the problem is identifying the key factor that is effective in revealing innovations. Thus, the foundations of innovation can be predicted and taken under control in the management of human resources (Tung, 1984). For this reason, this study aims to examine the effects of workplace belongingness on improving the current innovations and future innovations. This aim 


\section{F. Özsungur 12/2 (2020) 1788-1800}

was evaluated in the context of organizational change management, which reveals the understanding of adaptation to the new world order revealed by global change (Todnem By, 2005). Besides, the theory of social exchange, which is based on the idea of social interaction and the contribution of change to total benefit, was taken as a basis in the study (Blau, 1964; Lawler, 2001). On the other hand, the study is important in terms of strategic human resources management based on the efficient management principle of human resources (Collins, 2020). Because the relationship between the business strategy and human resources management can be revealed via this type of management (Bailey et al., 2018). On the other hand, competitive advantage, innovation, and flexibility are the requirements of strategic human resources management (Emeagwal \& Ogbonmwan, 2018). The sense of belonging, which is realized through social interaction, ensures the creation and performing of innovations in the adoption process brought about by the changes (Xie et al., 2018). The study is based on this idea.

\section{Workplace belongingness}

The workplace is the physical and virtual areas where individuals generate their financial income, occur social and corporate relationships, and have psychological and social outcomes. Factories, digital environments, offices are the working places. These environments where interpersonal relationships are established cause psychological and social interaction and outcomes (Baumeister \& Leary, 1995). The need for individuals to access financial resources improves emotional and physical interactions. These interactions enhance the sense of loyalty and belonging to the employer, other employers, stakeholders and workplace. Workplace climate and environmental factors play an important role in the development of these emotions. Factors such as friendship and peer relationships, leader influence, ethical principles, organizational culture, economic difficulties, career development, mission and vision of the organization enable the individual to adopt the workplace (Baumeister \& Leary, 1995; Lee and Robbins, 1995; Hagerty \& Patusky, 1995; Leary \& Cox, 2008; Malone et al., 2012). Workplace belongingness is the sum of these emotions.

Workplace belongingness emerges from the result of the employee comparing the values and positive climate set out in the workplace with their values and expectations (Leary et al., 2013). Belongingness emerges in an organizational structure where individual principles coincide with organizational identity, where justice and ethical principles are adopted, career development and fair human resources management are put forward, and the workplace climate provides benefits and positive value for the individual (Cockshaw et al., 2013). The idea of harmony, emotional intensity, and positivity related to the workplace, to which the individual devotes the majority of her/his life, results in workplace belongingness (Cockshaw et al., 2014).

The development of belongingness is possible with the individual opinion regarding the workplace, employees and organizational climate factors. Therefore, the existence of three basic factors is imperative to develop the employee's workplace belongingness: a) workplace-related factors (organizational climate, interpersonal relations, etc.) b) employee-related factors (psychology, emotions, motives, expectations, intentions, attitudes, etc.) c) employee-organization similarity (principles, acceptance, we-feeling, needs, vision, mission, values, etc.).

The belonging that is revealed by the interaction motivates the individual in the workplace and ensures that $\mathrm{s} /$ he enacts positive behaviors. In this case, it is an important problem about whether innovative behaviors are affected by workplace belongingness. Because it is crucial to reveal the effects of belonging behavior on innovative ideas and behaviors that contribute to the total performance of the business in the context of the outcomes of the business-employee interaction. Studies showed that workplace belongingness was associated with resilience and reduced distress (Shakespeare-Finch \& Daley, 2017), the predictor of compassion satisfaction and low levels of burnout (Somoray et al., 2017), related with culture (Mohamed et al., 2014) and depressive symptoms (Cockshaw et al., 2014), and that belongingness plays an intermediary role in the relationship between employee thriving and workplace incivility (Gkorezis et al., 2013).

\section{Exploratory innovation}

Innovations take advantage of existing know-how, knowledge, experience, and ideas (Phelps, 2010). Innovation is an important driving force in transferring the intellectual process into practice. For this reason, it is possible to discuss on two different innovative behavior patterns: exploratory and exploitative (Jansen et al., 2005). 


\section{F. Özsungur 12/2 (2020) 1788-1800}

Exploratory innovation is based on the idea that current information, technology, process, products, and services are not satisfactory (Wang et al., 2014). This type of innovation is inspired by the idea that information must come out of the mold and break its shell. Radical decisions and thoughts are essential for exploratory innovation. This is because changing consumer needs require proactive behavior and ideas beyond maintaining the current situation (Subramanian, 2012). Technology and economy are constantly evolving and changing (Huang et al., 2014). Adaptation to changing conditions requires creative ideas and practices beyond existing innovations. New markets, distribution channels, new consumers and customers, new products and services, new techniques are associated with the idea of exploratory innovation (Park \& Kim, 2015).

Beyond creativity, proactivity and current innovations, ideas and practices make a significant contribution to the workplace and organization (Hong et al., 2018). The performance of the company, entering new markets, increasing competitiveness, and revealing new distribution channels and processes are possible by this innovation ( $\mathrm{Li}$, Zhou \& Si, 2010). The relationship of exploratory innovative behaviors of employees or organization executives and belongingness has not been examined in the literature. Studies showed that innovation and employee commitment were associated (Eisenberger, Fasolo, \& Davis-LaMastro, 1990; Oeij, et al., 2012; Ottenbacher \& Gnoth, 2005), employee engagement was associated with creativity and innovation in the workplace (Gichohi, 2014; Andrew \& Sofian, 2012), ethical work climate, and trust was associated with commitment and innovation (Ruppel \& Harrington, 2000), affective commitment mediated the relationship between knowledge sharing and innovation performance (Camelo-Ordaz et al., 2011). Therefore, the first hypothesis of the study was created as follows:

\section{H1. Workplace belongingness is positively associated with exploratory innovation.}

Exploratory innovation is important for the sustainability and competitiveness of the organization (Srivastava, Sultan, \& Chashti, 2017). Competitors are constantly getting stronger, access to new markets becomes difficult, the financial and economical needs of the globalizing world are increasing, policies and laws require innovation in trade. It is an important fact that promotion strategies are not sufficient for sustainable competition in today's world. The development of technology and the differentiation of consumer needs made innovation in the design of products mandatory (Holak, \& Lehmann, 1990). The digital world has increased customer-business interactions, and it has become more difficult to obtain competitive power. For this reason, innovation must be beyond what is available in terms of product, service, distribution channels, design, market (Li, Zhang, \& Zheng, 2016). Thus, future markets, customers, new businesses, distribution channels, and design can emerge. On the other hand, maintaining existing innovations can provide significant benefits. This protection is possible with exploitative innovation.

\section{Exploitative innovation}

Organizations may have to maintain their current situation due to many factors such as economic difficulties, risks of entering new markets, few opportunities, epidemics, political and legal difficulties, and poor management (Heidhues, Kőszegi, \& Murooka, 2016). In this case, the existing innovations need to be improved for the organization to survive and not to catch rigor mortis (Zeng, Hu, \& Ouyang, 2017). In this case, the risk is minimized and the opportunities are investigated for the current product and service. Exploitative innovation is the protection and improvement of the innovation status achieved with the existing products, services, procurement, and processes (Jansen, Van Den Bosch, \& Volberda, 2006).

Improving existing products and services, increasing efficiency, carrying out innovative actions for existing customers, reducing the costs of internal processes are among the requirements of exploitative innovation (Jansen, Van den Bosch, \& Volberda, 2005). Going beyond stereotypes, radical ideas and actions are out of the scope of this type of innovation (Heidhues, Köszegi, \& Murooka, 2016). On the other hand, the fact that innovation involves the process of implementing a particular thought and idea raises some questions that need to be investigated. As demonstrated in the literature, innovation is an intellectual and operational component that includes elements such as new service, product, idea, method, technique, technology, process (Guan \& Liu, 2016). However, the intellectual foundation of exploratory innovation that goes beyond the boundaries and beyond improving the existing innovation raises the problem of the relationship between these two innovations. Therefore, the following question comes to mind. Does exploratory innovation depends on the emergence of exploitative innovation? In other words, is exploitative innovation effective in the 


\section{F. Özsungur 12/2 (2020) 1788-1800}

emergence of exploratory innovation? These questions are necessary to demonstrate whether current innovations provide an important insight to create innovations for future consumers.

It was revealed that formalization, positively influenced exploitative innovation (Jansen, Van Den Bosch, \& Volberda, 2006). According to another finding, it has been determined that organizational units with social relationships can demonstrate exploratory and exploitative innovations (Jansen, Van Den Bosch, \& Volberda, 2005). In the literature, it was revealed that exploratory and exploitative innovations were associated positively with firm performance ( $\mathrm{Li}, \mathrm{Zhou}$ \& Si, 2010), the organization regarding individual abilities, (Enkel et al., 2017), entrepreneurial leadership (Huang, Ding, \& Chen, 2014), in-group knowledge donating (Kamaşak \& Bulutlar, 2010). However, these studies do not prove the relationship between workplace belongingness, exploitative and exploratory innovations. Therefore, the last three hypotheses of the research were created as follows:

H2. Workplace belongingness is positively associated with exploitative innovation.

H3. Exploitative innovation is positively associated with exploratory innovation.

H4. Exploitative innovation mediates the association between workplace belongingness and exploratory innovation

\section{Methods}

\section{Participant}

The survey conducted with businesses that operated in the IT industry in Adana-Turkey and affiliated to the Adana Chamber of Commerce. The IT industry consists of organizations where innovations are frequently implemented. It is an important research subject to reveal the relationship between the current and future innovation behaviors and the belongingness behaviors in these organizations. On the other hand, this industry provides important services to the manufacturing and service industry regarding information, software, virtual, and digital. Researching these businesses that will provide information services in the context of outsourcing will make important contributions to other businesses. For this reason, the research survey was implemented to businesses that provide services to the manufacturing or service industry. In this context, the participants were asked the following question prior to the implementation of the questionnaire [Does your business provide services to the manufacturing or service industry? Yes ( ) No ( )]. The businesses, responded "No", were excluded from the scope of the study. The 46 businesses responded "No".

A purposeful random sampling method was adopted for sample selection (Guarte \& Barrios, 2006). Due to access to all IT businesses in Turkey was impossible, the sample was limited to the province of Adana. According to the data received from the Adana Chamber of Commerce, the number of enterprises operating in the IT industry in December 2019 was 175. The research was carried out with the general manager, manager, and CEOs of these enterprises. A survey was conducted with one manager from each business. Participants were selected from those who approved to contact information. Participants were informed that they could end the questionnaire at every stage of the study, the participation was voluntary, their information would be kept confidential and they could refuse the interview. Besides, information about the study and ethical issues were presented to the participants through the consent form.

A total of 137 survey form were implemented by face to face interviews with 137 companies. First of all, an invitation was sent to the company (phone, email, GSM) to conduct the survey 102 businesses refused this survey. 46 survey was excluded from the scope of the research due to not meeting the criteria. The number of surveys included in the research was determined as $91(\mathrm{~N}=175 ; \mathrm{n}=91)$.

\section{Measures}

The research survey consists of demographic information, workplace belongingness, exploratory innovation, and exploitative innovation scales. In order to eliminate common method biases, the scales of the questionnaire were organized in separate sections.

Workplace belongingness consists of 12 items. This scale was developed by Jena \& Pradhan (2018). The sample items of the scale are as follows: "I feel that there is a semblance between my organization and my own values and beliefs." "I generally carry more positive emotions than the negative ones during my job." "Being a part of 


\section{F. Özsungur 12/2 (2020) 1788-1800}

this organization inspires me to do more than what is expected.". This variable was measured with a Likert type scale in the range of 1-5 (1: strongly disagree; 5: strongly agree).

Exploratory innovation and exploitative innovation consists of seven items. These scales developed by Jansen, Van den Bosch, \& Volberda, (2006) were measured with Likert in the range of 1-5 (1: strongly disagree; 5: strongly agree). Sample items are as follows: Exploratory innovation: "Our unit accepts demands that go beyond existing products and services.", "We invent new products and services.", "We experiment with new products and services in our local market."; Exploitative innovation: "We frequently refine the provision of existing products and services.", "We regularly implement small adaptations to existing products and services.", "We introduce improved, but existing products and services for our local market."

\section{Procedure}

\section{Data analysis}

Confirmatory factor analysis (CFA) was applied to compare the theoretical structure with the estimated model and to determine the validity and reliability of the model (Harrington, 2009). This analysis was carried out with AMOS software. AMOS is a software recommended in the literature for determining the validity and reliability of complex models and discovering a model (Hu \& Bentler, 1999; Gefen et al., 2000). In this analysis, good fit values of $\chi 2, \chi 2 / \mathrm{df}$, RMSEA, SRMR, GFI, AGFI, CFI, IFI, NNFI (TLI) are determined. The obtained data are interpreted according to the threshold values recommended in the literature.

\section{Results}

\section{Demographics}

Gender, age, marital status, and education level were asked to obtain demographic information of the participants. Participitant's demographic variables were presented in Table 1.

Table 1. Demographic variables

\begin{tabular}{llcc}
\hline Demographics & & $\mathbf{f}$ & $\mathbf{\%}$ \\
\hline Gender & Female & 39 & 42,9 \\
Age & Male & 52 & 57,1 \\
& $18-23$ & 2 & 2,2 \\
& $24-29$ & 17 & 18,7 \\
& $30-35$ & 20 & 22,0 \\
& $36-41$ & 23 & 25,3 \\
& $42-47$ & 17 & 18,7 \\
Marital status & $48-53$ & 5 & 5,5 \\
& 54 and over & 7 & 7,7 \\
Education level & Single & 22 & 24,2 \\
& Married & 69 & 75,8 \\
& High School Graduate & 13 & 14,3 \\
& Bachelor's Degree & 68 & 74,7 \\
\hline
\end{tabular}

$\mathrm{f}$ : frequency; $\mathrm{n}=91 ; \% 100$

$42.9 \%$ of the participants were female and $57.1 \%$ were male. $47,3 \%$ of the participants were between the ages of $30-41.71,4 \%$ of the participants were married and $74,7 \%$ were bachelor's degrees.

\section{Confirmatory Factor Analysis}

Confirmatory factor analysis (CFA) is a type of analysis that reveals the structural validity of the model to be discovered (Byrne, 2013). This type of analysis provides reliable information in creating a complex model with sub-factors of the structure (Byrne, 1998). Good fit values indicate whether the model has been structurally validated at the end of the analysis. Before the analysis, the theoretical model is developed and analyzed to verify the structure (Tanaka, 1993). The estimated model determined in the research is presented in figure 1. 


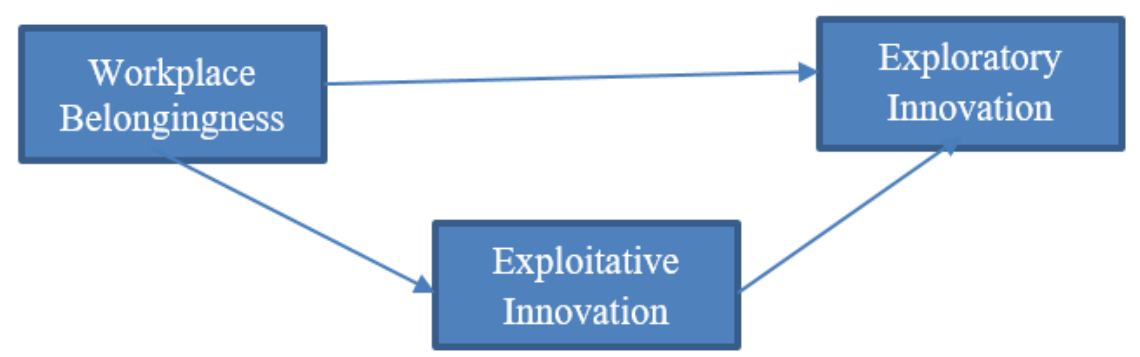

Figure 1. The research model

In CFA analysis, variables and items related to these variables were included in the analysis. As a result of the analysis, the initial data did not meet the good fit threshold values [ $\chi 2$ (91): 672,706, $\mathrm{p}<.01 ; \chi 2 / \mathrm{df:} 2,273$; RMSEA: .119; GFI: ,641; AGFI: .574; CFI: .824; IFI: .826; TLI: .807]. Two methods are recommended in the literature to provide threshold values (Brown, 2015). The first is to link items with high covariance loads to each other, and the other is to remove items (cut-offs) with low standardized regression weights from the proposed model (Field, 2005; Sharma et al., 2005). These procedures should also be appropriate for the purpose of the study (Stevens, 1992). First WB 6 (Standardized regression weight: .490) and then WB 2 (Standardized regression weight: .597) items were removed from the model. Items' standardized regression weights were over 0.60 and the items with high covariance values were linked to each other. Thus, the model met the criteria for threshold values at good fit values except for GFI and AGFI [ $\chi 2$ (91): 315,013, $p<.01 ; \chi 2 / \mathrm{df}: 1,522$; RMSEA: .076; GFI: ,787; AGFI: .716; CFI: .946; IFI: .947; TLI: .934]. In the literature, it is argued that if GFI and AGFI are below the threshold value, other values are acceptable (Brown, 2015; Hu \& Bentler, 1999). The reason for this is that these values are measured as low especially in small samples depending on the number of samples. The initial and final (modified) good fit values of the model are shown in table 2.

Table 2. Model Fit Coefficients

\begin{tabular}{|c|c|c|c|c|c|}
\hline $\begin{array}{l}\text { Fit } \\
\text { Index }\end{array}$ & $\begin{array}{l}\text { Initial } \\
\text { Model } \\
\text { Values } \\
\end{array}$ & $\begin{array}{l}\text { Modified } \\
\text { Model } \\
\text { Values } \\
\end{array}$ & $\begin{array}{l}\text { One Factor } \\
\text { Model } \\
\text { Values } \\
\end{array}$ & $\begin{array}{l}\text { Model Fit Threshold } \\
\text { Values }\end{array}$ & References \\
\hline$\chi^{2}$ & $\begin{array}{l}672,706 \\
p=.000\end{array}$ & $\begin{array}{l}315,013 \\
p=, 000\end{array}$ & $\begin{array}{l}1179,769 ; \\
\mathrm{p}=, 000 ; \Delta \mathrm{m} \chi^{2} \\
=864,756\end{array}$ & $\begin{array}{l}\text { Low } \chi^{2} \text { value; } \\
p<.01 ; p>.05\end{array}$ & $\begin{array}{l}\text { Hooper, Coughlan \& } \\
\text { Mullen (2008) }\end{array}$ \\
\hline$\chi^{2} / \mathrm{df}$ & 2,273 & 1,522 & 3,946 & $\begin{array}{l}\chi^{2} / \mathrm{df}<3 \\
\chi^{2} / \mathrm{df}<2\end{array}$ & $\begin{array}{l}\text { Wheaton, Muthen, Alwin } \\
\text { \& Summers (1977); Kline } \\
\text { (2005);Tabachnick \& Fidell } \\
\text { (2007) }\end{array}$ \\
\hline RMSEA & 119 & ,076 & 181 & $\begin{array}{l}\text { RMSEA }<.05-\text { Good } \\
\text { RMSEA }<.08- \\
\text { Acceptable }\end{array}$ & $\begin{array}{l}\text { Steiger (2007); Hu \& } \\
\text { Bentler (1999) }\end{array}$ \\
\hline GFI & 641 & 787 & ,356 & $\begin{array}{l}.95 \leq \mathrm{GFI} \leq 1 \mathrm{Good} \\
.90 \leq \mathrm{GFI} \leq .95 \\
\text { Acceptable }\end{array}$ & $\begin{array}{l}\text { Miles \& Shevlin (2007); } \\
\text { Tabachnick \& Fidell (2007) }\end{array}$ \\
\hline AGFI &, 574 & ,716 & ,244 & $\begin{array}{l}.90 \leq \text { AGFI } \leq 1.00 \text { Good } \\
.85 \leq \text { AGFI } \leq .90 \\
\text { Acceptable }\end{array}$ & Tabachnick \& Fidell (2007) \\
\hline CFI & 824 & ,946 & ,588 & $\begin{array}{l}.95 \leq \mathrm{CFI} \leq 1.00 \text { Good } \\
.90 \leq \mathrm{CFI} \leq .95 \\
\text { Acceptable }\end{array}$ & $\begin{array}{l}\text { Schumacker \& Lomax, } \\
\text { (1996); Hu \& Bentler } \\
\text { (1999) }\end{array}$ \\
\hline IFI & 826 & ,947 & ,593 & $\begin{array}{l}95 \leq \mathrm{IFI} \leq 1.00 \text { Good } \\
.90 \leq \mathrm{IFI} \leq .95 \text { Acceptable }\end{array}$ & Miles \& Shevlin (2007) \\
\hline $\begin{array}{l}\text { NNFI } \\
\text { (TLI) }\end{array}$ & ,807 & ,934 & ,553 & $\begin{array}{l}.97 \leq \mathrm{NNFI} \leq 1 \text { Good } \\
\text { NNFI }>0.90 \text { Acceptable }\end{array}$ & $\begin{array}{l}\text { Hu \& Bentler (1999); } \\
\text { Fan, Thompson \& Wang } \\
\text { (1999) } \\
\text { Bentler \& Bonett (1980) }\end{array}$ \\
\hline
\end{tabular}


$\chi^{2}$ Discrepancy Chi Square; $\chi^{2} / \mathrm{df}$ (Chi Square/Degrees of Freedom); GFI (Goodness of Fit Index); NNFI (NonNormed Fit Index); SRMR (Standardized Root Mean Square Residual CFI (Comparative Fit Index); IFI (Incremental Fit Index); RMSEA (Root Mean Square of Error Approximation);); AGFI (Adjusted Goodness of Fit); TLI (Tucker-Lewis Index)

In conducting a survey where the sample is greater than 30, parametric tests should be examined in the context of common method biases (Podsakoff \& Organ, 1986). During the preparation of the questionnaires, some actions need to be taken to eliminate the prejudices of the participants regarding the survey items and to prevent the researcher's effects on the measurement tools. In this context, while preparing the survey questions, the original scale items were adhered to and analysis was made for the language validity. The original form was translated into Turkish, retranslated into English and the differences were analyzed by a team of 7 experts. Turkish and English forms were compared for content validity. The translations were performed by two experts whose native language is English and Turkish. The final questionnaire form with proven language validity was applied to a group of 49 people ( 28 males; 21 females). The clarity of the items was voted by the participants by the Likert scale. Thus, the content validity of measurement tools was proved.

In the literature, the one-factor method is recommended for common method biases (CMB) that may occur in measurement tools. In this method, the model whose tested structure validity is compared with the one-factor structure (MacKenzie and Podsakoff, 2012). As can be seen from Table 2, it is proved that CMB did not exist for the current model as a result of comparison with the single factor structure $\left(\Delta_{\mathrm{m}} \chi 2=864,756 ; \mathrm{p}<.01\right)$. However, this method is criticized in the literature. Another recommended method is the three-phase CFA marker technique (Williams, Hartman and Cavazotte, 2010). Depending on this method, two factors, common and latent, were added to the model. According to the results of this analysis performed in 3 Phase (Baseline $\rightarrow$ Method-C; Method-C $\rightarrow$ Method-U; Method-U $\rightarrow$ Method-R), there was no CMB in research tools (MacKenzie and Podsakoff, 2012).

The variables and items of the research model are as follows: workplace belongingness (12 items), exploratory innovation (seven items), exploitative innovation (seven items). Discriminant and convergent validity, a subtype of structure validity, were applied to determine the association of this model structure with the theoretical structure. In this type of analysis, average variance extracted (AVE), maximum shared variance (MSV), composite reliability (CR), maximum reliability (MaxRH), and the square root of AVE (a) values are determined (Maruyama, 1998). These values were determined as follows: EXIN ( $\alpha$ : .892; CR: .899; AVE: .562; MSV: .789; MaxRH: .928; a . 749) WORKB ( $\alpha$ : .954; CR: .958; AVE: .696; MSV: .350; MaxRH: .860; a . .834), EXPIN ( $\alpha$ : .920; CR: .930; AVE: .691; MSV: .789; MaxRH: .865; a . .831). If AVE values are higher than 0.5 and CR values are higher than 0.70 , low values in other coefficients do not affect discriminant and convergent validity (Hu \& Bentler, 1999; Kline, 2016; Fornell \& Larcker, 1981; Hair et al., 2016; Nunnally, 1976). In light of this information, the model proved to have discriminant and convergent validity (Table 3 ).

Table 3. Discriminant and Convergent Validity

\begin{tabular}{lcccccccc}
\hline Variables & $\boldsymbol{\alpha}$ & CR & AVE & MSV & MaxR(H) & EXIN & WORKB & EXPIN \\
\hline EXIN & .892 & 0,899 & 0,562 & 0.789 & 0,928 & $0,749^{a}$ & & \\
WORKB & .954 & 0,958 & 0,696 & 0.350 & 0,860 & $0,592^{*}$ & $0,834^{\text {a }}$ & \\
EXPIN & .920 & 0,930 & 0,691 & 0.789 & 0,865 & $0,888^{*}$ & $0,532^{*}$ & $0,831^{\text {a }}$ \\
\hline
\end{tabular}

WORKB: workplace belongingness; EXIN: exploratory innovation; EXPIN: exploitative innovation; $\alpha=$ Cronbach's alpha; $\operatorname{MaxR}(\mathrm{H})=$ maximum reliability; a Square root of $\mathrm{AVE}$ value; $\mathrm{MSV}=$ maximum shared variance; $C R=$ composite reliability; $A V E$ value is significant over $0.50, C R$ is acceptable at the level of 0.7 and above; $\mathrm{AVE}=$ average variance extracted; ${ }^{*}$ Pearson Correlation.

\section{Mediation Analysis}

IBM SPSS AMOS software was used for the mediation analysis. As suggested in the literature, the fact that total variance explained is above $80 \%$ proves full mediation, values between $20 \%$ and $80 \%$ show a partial mediation (Hayes, 2013; Howell, 2010). On the other hand, the bootstrapping method is recommended in mediation analysis. This is because the data obtained by this method provides evidence that produces reliable estimates for larger samples (Sacchi, 1998). After the model predicted in the mediation analysis reaches the 


\section{F. Özsungur 12/2 (2020) 1788-1800}

structure that provides good fit values, the mediation model is created. On the other hand, the bootstrapping method enables the determination of indirect effects (Hair et al., 2016, 2006). This model provides a close examination of the structure obtained as a result of the confirmatory factor analysis in the context of direct and indirect effects. AMOS enables to reveal models that have not been tested before in this context. Analysis results for mediation analysis are presented in table 4 .

Table 4. Mediation Analysis Results

\begin{tabular}{cccccccc}
\hline EXPIN & $\begin{array}{c}\text { Total } \\
\text { Effects }\end{array}$ & $\begin{array}{c}\text { Direct } \\
\text { Effects }\end{array}$ & $\begin{array}{c}\text { Indirect } \\
\text { Effects }\end{array}$ & $\begin{array}{c}\text { Lower } \\
\text { Bounds }\end{array}$ & $\begin{array}{c}\text { Upper } \\
\text { Bounds }\end{array}$ & p & Mediation Effect \\
\hline $\begin{array}{c}\text { WORKB - } \\
\text { EXIN }\end{array}$ &, 511 &, 149 &, 362 &, 243 &, 529 &, $001^{* * *}$ & $\begin{array}{c}\text { Partially } \\
\text { (TVE:26,2\%) }\end{array}$ \\
\hline
\end{tabular}

Notes: WORKB: workplace belongingness; EXIN: exploratory innovation; EXPIN: exploitative innovation.

The confidence interval values for indirect effects were calculated by bootstrap with $\mathrm{N}=910$. TVE: Total variance explained; ${ }^{* * *}$ the $\mathrm{p}$-value is significant at 0.01 (two tailed); ${ }^{*}$ the p-value is significant at 0.1 (two tailed); **the p-value is significant at 0.05 (two tailed); Perform bootstrap: 910; Bias-corrected confidence intervals: 95\%; percentile confidence intervals: $90 \%$ )

The standardized total (direct and indirect) effect of WORKB on EXIN was determined as 0,511. The standardized direct (unmediated) effect of WORKB on EXIN was detected as 0,149 . The standardized indirect (mediated) effect of WORKB on EXIN was calculated as 0,362. 0,243 is the lower endpoint and 0,529 is the upper endpoint of a two-sided bias-corrected bootstrap confidence interval for the standardized indirect (mediated) effect of WORKB on EXIN.

The total variance explained ratio (TVE) of the mediator was determined with squared multiple correlations. It is estimated that the predictors of EXPIN explain 26,2 percent of its variance (WORKB $\rightarrow$ EXPIN $\rightarrow$ EXIN). In other words, the error variance of EXPIN is approximately 73,8 percent of the variance of EXPIN itself. The findings showed that EXPIN played a mediation role in the effect of WORKB on EXIN (figure 2).

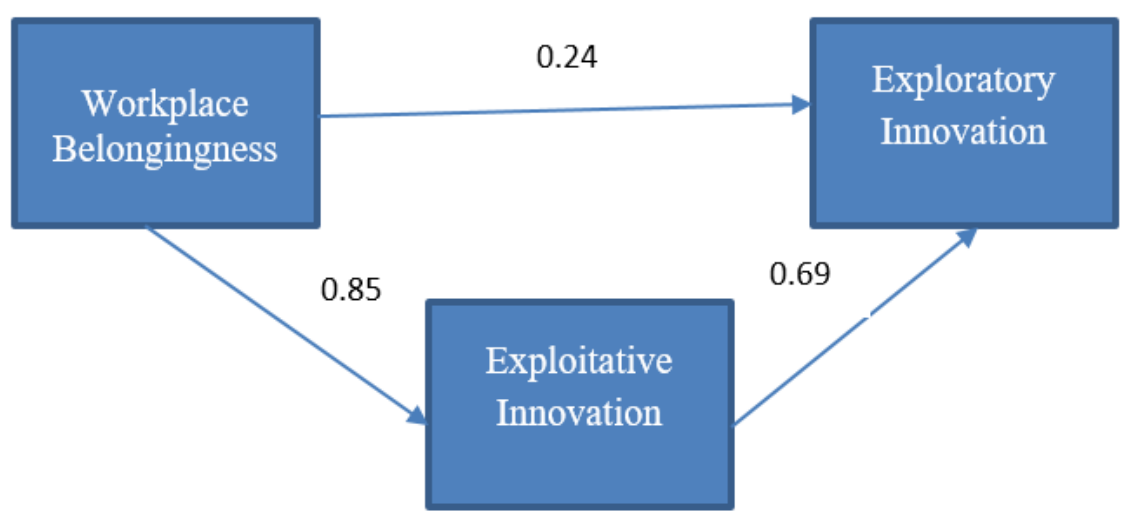

Figure 2. Mediation model with standardized estimates

Results of hypotheses

According to the findings, there was a positive and significant association between WORKB $\rightarrow$ EXIN (H1: $\beta=.240 \mathrm{t}=2,261 ; \mathrm{p}<0,05)$, WORKB $\rightarrow$ EXPIN (H2: $\beta=.849 \mathrm{t}=5,015 ; \mathrm{p}<0,01)$, and EXPIN $\rightarrow$ EXIN (H3: $\beta=.687 \mathrm{t}=6,280$; $\mathrm{p}<0,01$ ). Thus, H1, H2, H3 hypotheses regarding direct effects were supported (table 5).

Table 5. Research hypotheses test results for direct effects table.

\begin{tabular}{lccccc}
\hline \multicolumn{1}{c}{ Alternative Hypotheses } & Conclusion & $\mathbf{t}(910)$ & $\beta$ & $p$ \\
\hline H1.WORKB $\rightarrow$ EXIN & Supported & 2,261 &, 240 & $0.024^{* *}$ & \\
H2.WORKB $\rightarrow$ EXPIN & Supported & 5,015 &, 849 & $0.001^{* * *}$ \\
H3.EXPIN $\rightarrow$ EXIN & Supported & 6,280 &, 687 & $0.001^{* * *}$ \\
\hline
\end{tabular}

$\mathrm{t}$ : Critical ratio; $\beta$, Standard Beta; ${ }^{*} 0.1$ level (2-tailed); ${ }^{* *}$ the $\mathrm{p}$-value is significant at 0.05 level (2-tailed) ${ }^{* * *}$ the $\mathrm{p}$-value is significant at 0.01 level (2-tailed). 
Mediation analysis results showed that the effects of the exogenous variable (WORKB) on the endogenous variable $(E X I N)$ were significant [WORKB $\rightarrow$ EXPIN $\rightarrow$ EXIN; $t(910)=.243 \leftrightarrow .529 ; p<0,001 ;$ TVE: $26,2 \%$ ]. Thus, the H4 hypothesis was supported.

\section{Discussion and Conclusion}

According to the results of the study, the workplace has positive effects on workplace belongingness, exploratory and exploitative innovations. These positive effects show the effects of employees' sense of belonging on the act of creativity. The fact that this effect will improve existing innovations and provide a prediction for different innovations beyond borders will make significant contributions in the context of human resources management, and change management. The reason for the effects of workplace belonging on exploitative innovation may be due to social interaction in the workplace, organizational climate, positive effects of the organization in career development, leader-employee interaction. The effects of employee commitment and engagement in the workplace on the innovative actions and ideas of the business reveal the importance of the factors affecting belonging. Associations between employee commitment, affective commitment, employee engagement, and innovation have been revealed in the literature (Camelo-Ordaz et al., 2011; Eisenberger et al., 1990; Oeij, et al. , 2012; Ottenbacher \& Gnoth, 2005; Gichohi, 2014; Andrew \& Sofian, 2012). The effects of organizational climate on innovation have also been proven in the literature (Ruppel \& Harrington, 2000). However, these findings are factors that affect belonging and are not sufficient to prove the effects of engagement directly.

The reason for the research findings on the effects of workplace belongingness on exploratory innovation may be due to the perception of career opportunities and the feasibility of future strategies. The belief that the current innovations are not sufficient with a visionary approach shows that the individuals have high expectations in the context of their belonging to the workplace. These innovative ideas and actions enable the individual's plans and workplace ideas to go beyond the limits and get out of the molds. The exploitative innovation found to mediate this association shows that it is a creative and inspiring resource for different innovations. New businesses, processes, products, and services are inspired by existing innovations. Therefore, current innovative knowledge and experience are necessary and important for future innovations.

The effect of belonging to the workplace on the improvement and development of existing innovations reveals the importance of the sense of belonging in the context of human resources management. In practice, businesses can incorporate in their business strategies the finding that the sense of belonging needs to be developed to realize innovative ideas and actions to be revealed by the human resource. Developing belonging and innovations in strategic human resources management can affect the overall performance and efficiency of the organization. For this reason, the development of the workplace belongingness is necessary for businesses.

Research findings revealed the effects of workplace belongingness on innovation. However, the main factors that provide belongingness on the effects of workplace belongingness on exploratory and exploitative innovations can be determined by qualitative research. For this reason, it is recommended to carry out qualitative research for future studies. Theoretically proved findings of revealing the association between belongingness and innovation require researches for different types of organizations. On the other hand, it is recommended to examine the association with workplace belongingness, the two innovation types, leadership, service innovation performance, entrepreneurship, psychological empowerment, and psychological capital.

Although there is no similar study in the literature, it has some limitations. The limited number of samples, the realization of the study only with business executives is among the limitations of the study (Converse \& Presser, 1986). The implementation of the study to blue-collar employees will contribute to the literature. 


\section{References}

Andrew, O. C., \& Sofian, S. (2012). Individual factors and work outcomes of employee engagement. ProcediaSocial and behavioral sciences, 40, 498-508.

Bailey, C., Mankin, D., Kelliher, C., \& Garavan, T. (2018). Strategic human resource management. Oxford University Press.

Blau, P. (1964). Exchange and power in social life. New York, NY: Wiley \& Sons.

Baumeister, R. F., \& Leary, M. R. (1995). The need to belong: desire for interpersonal attachments as a fundamental human motivation. Psychological bulletin, 117(3), 497.

Bentler P M \& Bonett D G. (1980). Significance tests and goodness of lit in the analysis of covariance structures. Psychol. Bull., 88, 588-606.

Brown, T. A. (2015). Confirmatory factor analysis for applied research. Guilford Publications.

Byrne, B. M. (2013). Structural equation modeling with amos: basic concepts, applications, and programming (Second Edition). Taylor \& Francis.

Byrne, B.M. (1998). Structural Equation Modeling with LISREL, PRELIS and SIMPLIS: Basic Concepts, Applications and Programming. Mahwah, New Jersey: Lawrence Erlbaum Associates.

Bysted, R. (2013). Innovative employee behaviour. European Journal of Innovation Management. 16(3), 268-284.

Camelo-Ordaz, C., Garcia-Cruz, J., Sousa-Ginel, E., \& Valle-Cabrera, R. (2011). The influence of human resource management on knowledge sharing and innovation in Spain: the mediating role of affective commitment. The International Journal of Human Resource Management, 22(07), 1442-1463.

Cockshaw, W. D., Shochet, I. M., \& Obst, P. L. (2014). Depression and belongingness in general and workplace contexts: A cross-lagged longitudinal investigation. Journal of Social and Clinical Psychology, 33(5), 448462.

Cockshaw, W.D., Shochet, I.M. and Obst, P.L. (2013), “General belongingness, workplace belongingness, and depressive symptoms", Journal of Community and Applied Social Psychology, Vol. 23 No. 3, pp. 240251.

Collins, C. J. (2020). Expanding the resource based view model of strategic human resource management. The International Journal of Human Resource Management, 1-28.

Converse, J. M., \& Presser, S. (1986), Survey questions: Handcrafting the standardized questionnaire, Newbury Park, CA: Sage Publications.

Davey, K. S., \& Sanders, T. J. (2012). Serial strategic innovation and sustainable competitive advantage: A longitudinal case study. Journal of Case Research in Business and Economics, 4, 1.

Disney, J. (1999). Customer satisfaction and loyalty: The critical elements of service quality. Total Quality Management, 10(4-5), 491-497.

Eisenberger, R., Fasolo, P., \& Davis-LaMastro, V. (1990). Perceived organizational support and employee diligence, commitment, and innovation. Journal of Applied Psychology, 75(1), 51-59. https://doi.org/10.1037/0021-9010.75.1.51

Emeagwal, L., \& Ogbonmwan, K. O. (2018). Mapping the perceived role of strategic human resource management practices in sustainable competitive advantage. Academy of Strategic Management Journal.

Enkel, E., Heil, S., Hengstler, M., \& Wirth, H. (2017). Exploratory and exploitative innovation: To what extent do the dimensions of individual level absorptive capacity contribute?. Technovation, 60, 29-38.

Fan, X., Thompson, B. \& Wang, L. (1999). Effects of Sample Size, Estimation Methods, and Model Specification on Structural Equation Modeling Fit Indexes. Structural Equation Modeling, 6 (1), 56-83.

Field, A.(2005). Discovering Statistics Using SPSS, 2nd edn, London: SAGE. 


\section{F. Özsungur 12/2 (2020) 1788-1800}

Fornell, C. \& Larcker, D. F. (1981). Evaluating structural equation models with unobservable variables and measurement error. Journal of marketing research, 39-50.

Frambach, R. T., \& Schillewaert, N. (2002). Organizational innovation adoption: A multi-level framework of determinants and opportunities for future research. Journal of business research, 55(2), 163-176.

Gefen, D., Straub, D. \& Boudreau, M.-C. (2000). Structural Equation Modeling and Regression: Guidelines for Research Practice. Communications of the Association for Information Systems, 4(1), 2-77.

Gichohi, P. M. (2014). The role of employee engagement in revitalizing creativity and innovation at the workplace: a survey of selected libraries in Meru County--Kenya. Library Philosophy and Practice.

Gkorezis, P., Kalampouka, P., \& Petridou, E. (2013). The mediating role of belongingness in the relationship between workplace incivility and thriving. International Journal of Employment Studies, 21(2), 63.

Guan, J., \& Liu, N. (2016). Exploitative and exploratory innovations in knowledge network and collaboration network: A patent analysis in the technological field of nano-energy. Research policy, 45(1), 97-112.

Guarte, J. M., \& Barrios, E. B. (2006). Estimation under purposive sampling. Communications in StatisticsSimulation and Computation, 35(2), 277-284.

Hagerty, B.M. and Patusky, K. (1995), “Developing a measure of sense of belonging”, Nursing Research, 44(1), 9-13.

Hair, J. F., Black, W. C., Babin, B. J., Anderson, R. E., \& Tatham, R. L. (2006), Multivariate data analysis (6th ed.), Upper Saddle River, NJ: Prentice-Hall.

Hair Jr, J. F., Hult, G. T. M., Ringle, C. \& Sarstedt, M. (2016). A primer on partial least squares structural equation modeling (PLS-SEM). Sage Publications.

Harrington, D. (2009). Confirmatory factor analysis. Oxford university press.

Hayes, A. F. (2013). Mediation, moderation, and conditional process analysis. Introduction to Mediation, Moderation, and Conditional Process Analysis: A Regression-Based Approach. New York: Guilford Publications, 1-20.

Heidhues, P., Kőszegi, B., \& Murooka, T. (2016). Exploitative innovation. American Economic Journal: Microeconomics, 8(1), 1-23.

Holak, S. L., \& Lehmann, D. R. (1990). Purchase intentions and the dimensions of innovation: An exploratory model. Journal of Product Innovation Management: an international publication of the product development $\mathcal{E}$ management association, 7(1), 59-73.

Hong, J., Hou, B., Zhu, K., \& Marinova, D. (2018). Exploratory innovation, exploitative innovation and employee creativity. Chinese Management Studies.12(2), 268-286.

Hooper, D., Coughlan, J. \& Mullen, M. (2008). Structural equation modelling: guidelines for determining model fit. Electronic Journal of Business Research Methods, 6(1), 53-60.

Howell, D. C. (2010). Statistical Methods for Psychology. 7. Ed. Belmont: Wadsworth, Cengage Learning.

Hu, L. \& Bentler, P.M. (1999). Cutoff Criteria for Fit Indexes in Covariance Structure Analysis: Conventional Criteria Versus New Alternatives. Structural Equation Modeling: A Multidisciplinary Journal, 6(1), 1-55.

Huang, S., Ding, D., \& Chen, Z. (2014). Entrepreneurial Leadership and Performance in C hinese New Ventures: A Moderated Mediation Model of Exploratory Innovation, Exploitative Innovation and Environmental Dynamism. Creativity and Innovation Management, 23(4), 453-471.

Jansen, J. (2005). Ambidextrous organizations: a multiple-level study of absorptive capacity, exploratory and exploitative innovation and performance (No. 55). ERIM Ph.D. Series Research in Management. Erasmus University Rotterdam. Retrieved from http://hdl.handle.net/1765/6774

Jansen, J. J., Van den Bosch, F. A., \& Volberda, H. W. (2005). Exploratory innovation, exploitative innovation, and ambidexterity: The impact of environmental and organizational antecedents. Schmalenbach Business Review, 57(4), 351-363. 


\section{F. Özsungur 12/2 (2020) 1788-1800}

Jansen, J. J., Van Den Bosch, F. A., \& Volberda, H. W. (2006). Exploratory innovation, exploitative innovation, and performance: Effects of organizational antecedents and environmental moderators. Management science, 52(11), 1661-1674.

Jeffres, L., \& Atkin, D. (1996). Predicting use of technologies for communication and consumer needs. Journal of Broadcasting \& Electronic Media, 40(3), 318-330.

Jena, L. K., \& Pradhan, S. (2018). Conceptualizing and validating workplace belongingness scale. Journal of Organizational Change Management.

Kamaşak, R., \& Bulutlar, F. (2010). The influence of knowledge sharing on innovation. European Business Review.

Kline, R.B. (2005). Principles and Practice of Structural Equation Modeling (2nd Edition ed.). New York: The Guilford Press.

Kline R. B. (2016). Principles and Practices of Structural Equation Modeling (4th Edn). New York, NY: The Guilford Press.

Lawler, E. J. (2001). An affect theory of social exchange. American journal of sociology, 107(2), 321-352.

Leary, M.R. and Cox, C.B. (2008), "Belongingness motivation: a mainspring of social action", in Shah, J.Y. and Gardener, W.L. (Eds), Handbook of Motivation Science, Guilford, New York, NY, pp. 27-40.

Lee, R. M., \& Robbins, S. B. (1995). Measuring belongingness: The social connectedness and the social assurance scales. Journal of counseling psychology, 42(2), 232.

Li, Y., Zhou, N., \& Si, Y. (2010). Exploratory innovation, exploitative innovation, and performance. Nankai Business Review International.

Li, Y., Zhang, Y., \& Zheng, S. (2016). Social capital, portfolio management capability and exploratory innovation: evidence from China. Journal of Business $\mathcal{E}$ Industrial Marketing.

MacKenzie, S.B., \& Podsakoff, P.M. (2012). Common method bias in marketing: Causes,mechanisms, and procedural remedies. Journal of Retailing, 88, 4, 542-555.

Malone, G.P., Pillow, D.R. and Osman, A. (2012), “The general belongingness scale (GBS): assessingachieved belongingness", Personality and Individual Differences, Vol. 52 No. 3, pp. 311-316.

Maruyama, G. M. (1998). Basics of structural equation modeling. Thousand Oaks, CA, US: SagePublications, Inc.

Miles, J. \& Shevlin, M. (2007). A time and a place for incremental fit indices. Personality and Individual Differences, 42(5), 869-874.

Mohamed, Z. N. J. M. M. L., Newton, J. M., \& McKenna, L. (2014). Belongingness in the workplace: a study of M alaysian nurses' experiences. International Nursing Review, 61(1), 124-130.

Nunnally, J. C. (1976). Psychometric theory (2nd ed). New York: McGraw-Hill.

Oeij, P., Dhondt, S., Kraan, K., Vergeer, R., \& Pot, F. D. (2012). Workplace Innovation and its Relations with Organisational Performance and Employee Commitment-www-publicatie.

Ottenbacher, M., \& Gnoth, J. (2005). How to develop successful hospitality innovation. Cornell hotel and restaurant administration quarterly, 46(2), 205-222.

Podsakoff, P. M., \& Organ, D. W. (1986), "Self-reports in organizational research: Problems and prospects", Journal of Management, Vol. 12 No. 4, pp.531-544.

Park, J., \& Kim, S. (2015). The differentiating effects of workforce aging on exploitative and exploratory innovation: The moderating role of workforce diversity. Asia Pacific Journal of Management, 32(2), 481503.

Phelps, C. C. (2010). A longitudinal study of the influence of alliance network structure and composition on firm exploratory innovation. Academy of management journal, 53(4), 890-913. 


\section{F. Özsungur 12/2 (2020) 1788-1800}

Ruppel, C. P., \& Harrington, S. J. (2000). The relationship of communication, ethical work climate, and trust to commitment and innovation. Journal of business Ethics, 25(4), 313-328.

Sacchi, M.D. (1998). A bootstrap procedure for high-resolution velocity analysis. Geophysics, 63(5), 1716-1725.

Saebi, T., \& Foss, N. J. (2015). Business models for open innovation: Matching heterogeneous open innovation strategies with business model dimensions. European Management Journal, 33(3), 201-213.

Schumacker, R.E. \& Lomax, R.G. (1996). A Beginner's Guide to Structural Equation Modeling. Mahwah. New Jersey: Lawrence Erlbaum Associates, Publishers.

Shakespeare-Finch, J., \& Daley, E. (2017). Workplace belongingness, distress, and resilience in emergency service workers. Psychological Trauma: Theory, Research, Practice, and Policy, 9(1), 3235. https://doi.org/10.1037/tra0000108.

Sharma, S., Mukherjee, S., Kumar, A., \& Dillon, W.R. (2005). A simulation study to investigate the use of cutoff values for assessing model fit in covariance structure models. Journal of Business Research, 58 (1), 935943.

Somoray, K., Shakespeare-Finch, J., \& Armstrong, D. (2017). The impact of personality and workplace belongingness on mental health workers' professional quality of life. Australian Psychologist, 52(1), 5260.

Srivastava, S., Sultan, A., \& Chashti, N. (2017). Influence of innovation competence on firm level competitiveness: an exploratory study. Asia Pacific Journal of Innovation and Entrepreneurship.

Steiger, J.H. (2007). Understanding the limitations of global fit assessment in structural equation modeling. Personality and Individual Differences, 42(5), 893-898.

Stevens, J.P. (1992). Applied Multivariate Statistics for the Social Sciences (2 nd edition). Hillsdale, NJ: Erlbaum.

Subramanian, A. M. (2012). A longitudinal study of the influence of intellectual human capital on firm exploratory innovation. IEEE Transactions on Engineering Management, 59(4), 540-550.

Tabachnick, B.G. \& Fidell, L.S. (2007). Using Multivariate Statistics (5 ${ }^{\text {th }}$ edition). New York: Allyn and Bacon.

Talukder, M., \& Quazi, A. (2011). The impact of social influence on individuals' adoption of innovation. Journal of Organizational Computing and Electronic Commerce, 21(2), 111-135.

Todnem By, R. (2005). Organisational change management: A critical review. Journal of change management, 5(4), 369-380.

Tanaka, J. S. (1993). Multifaceted conceptions of fit in structural equation models. In J. A. Bollen \&J. S. Long (Eds), Testing structural equation models (pp. 10-39). Newbury Park, CA: Sage.

Tung, R. L. (1984). Strategic management of human resources in the multinational enterprise. Human resource management, 23(2), 129-143.

Wang, C., Rodan, S., Fruin, M., \& Xu, X. (2014). Knowledge networks, collaboration networks, and exploratory innovation. Academy of Management Journal, 57(2), 484-514.

Wheaton, B., Muthen, B., Alwin, D. F. \& Summers, G. F. (1977). Assessing Reliability and Stability in Panel Models. In David R. Heise (Ed.). Sociological Methodology Jossey-Bass (84-136). San Francisco.

Williams, L. J., Hartman, N. \& Cavazotte, F. (2010), “Method Variance and Marker

Variables: A Review and Comprehensive CFA Marker Technique", Organizational ResearchMethods, 13 (3), 477514.

Xie, Y., Xue, W., Li, L., Wang, A., Chen, Y., Zheng, Q., ... \& Li, X. (2018). Leadership style and innovation atmosphere in enterprises: An empirical study. Technological Forecasting and Social Change, 135, 257265.

Zeng, D., Hu, J., \& Ouyang, T. (2017). Managing innovation paradox in the sustainable innovation ecosystem: A case study of ambidextrous capability in a focal firm. Sustainability, 9(11), 2091. 